\title{
A multianalytical approach to investigate stone biodeterioration at a UNESCO world heritage site: the volcanic rock-hewn churches of Lalibela, Northern Ethiopia
}

\author{
Nick Schiavon - Tilde De Caro - Alemayehu Kiros • \\ Ana Teresa Caldeira · Isabella Erica Parisi · \\ Cristina Riccucci • Giovanni Ettore Gigante
}

Received: 16 April 2013 / Accepted: 30 April 2013

(c) Springer-Verlag Berlin Heidelberg 2013

\begin{abstract}
A multianalytical approach combining Optical Microscopy (OM), Backscattered Variable Pressure Scanning Electron Microscopy + Energy Dispersive X-ray Spectroscopy (VP-BSEM + EDS), Powder X-ray Diffractometry (PXRD), Raman Spectroscopy, and Microbiological techniques has been applied to characterize decay products and processes occurring at the surface of two rockhewn churches (Bete Gyorgis and Bete Amanuel) at the UNESCO's World Heritage site of Lalibela, Northern Ethiopia. The two churches were carved into volcanic scoria deposits of basaltic composition. In their geological history, the Lalibela volcanic rocks underwent late to post-magmatic hydrothermal alteration together with partial laterization and are therefore characterized by a decay-prone highly vesicular microtexture with late stage to post-magmatic precipitation of secondary mineral phases (calcite-zeolite-smectite). The main objective of the study was to gain a better insight into the weathering products and mechanisms affecting the surface of the stone monuments and to assess the relative
\end{abstract}

N. Schiavon $(\varangle)$

HERCULES Laboratory and Évora Geophysics Centre (CGE),

University of Évora, Évora, Portugal

e-mail: schiavon@uevora.pt

T. De Caro · I.E. Parisi · C. Riccucci

CNR-ISMN, Rome, Italy

\section{A. Kiros}

Department of Physics, University of Addis Ababa, Addis Ababa, Ethiopia

\author{
A.T. Caldeira \\ Department of Chemistry, University of Évora, Évora, Portugal \\ G.E. Gigante \\ Department SBAI, Sapienza University of Rome, Rome, Italy
}

contribution of natural "geological" weathering processes versus biological/salt attack in stone decay at this unique heritage site. Results indicate that while the main cause of bulk rock deterioration and structural failure could be related to the stone inherited "geological" features, biological attack by micro- (bacteria) and/or macro- (lichens) organisms is currently responsible for severe stone surface physical and chemical weathering leading to significant weakening of the stone texture and to material loss at the surface of the churches walls. A prompt and careful removal of the biological patinas with the correct biocidal treatment is therefore recommended.

\section{Introduction}

The Lalibela UNESCO World Heritage site is located near the rural town of Lalibela, $600 \mathrm{~km}$ north of Addis Ababa, in Northern Ethiopia at an altitude of $2500 \mathrm{~m}$ above s.1. The town has 12.000 inhabitants and hosts a unique complex of eleven rock-hewn churches (Fig. 1) believed to have been carved in the 12 th century A.D. by the King Lalibela (1167-1207) of the Zagwe dynasty [1]. The churches are still used today for religious practices and ceremonies, and on the occasion of major religious events, large crowds of believers and pilgrims gather at the site mingling with an increasing flux of foreign tourists. According to their geographical distribution (Fig. 1), the churches are traditionally subdivided into three main groups: the first one comprises 6 churches, i.e., Bete Medhane Alem (Church of the Holy Saviour), Bete Marian (St. Mary's Church), Bete Mesqel (Church of the Cross), Bete Denagel (Virgins Church), Bete Debre Sina (Mount Sinai Church), and Bete Golgotha (Golgotha Church); the second one comprises 4 churches, i.e., Bete Gabriel-Rufael (Church of S. Gabriel/Rafael), Bete 